\title{
Voluntary feed intake and growth performance of boars and barrows in dependence on lysine-to-energy ratio
}

\author{
Caroline Otten, Andreas Berk and Sven Dänicke \\ Institute of Animal Nutrition, Friedrich-Loeffler-Institute (FLI), Federal Research Institute for Animal Health, \\ Braunschweig, Germany
}

\begin{abstract}
Boars (entire male pigs) consume less feed than barrows (castrated male pigs) under practical ad libitum feeding conditions, but the knowledge about possible reasons is only limited. Since the lysine and energy contents of the diet are known to be important determinants of voluntary feed intake, it was of interest if sex specific responses to selected dietary lysine-toenergy ratios could explain the differences in feed intake between boars and barrows.

A total of 95 pigs ( 48 boars and 47 barrows) was used for this investigation. Four diets were fed with two different precaecally digestible lysine-to-metabolised energy (ME) ratios, 0.93 and $0.86(\mathrm{~g} / \mathrm{MJ})$ for grower diets and 0.71 and $0.66(\mathrm{~g} / \mathrm{MJ})$ for finisher diets. The pigs were kept individually and divided into four feeding groups for each sex. A $2 \times 2 \times 2$ factorial design with the factors sex (boars vs. barrows), lysine level and energy level was employed. The sex effect was dominant and influenced all variables $(P<0.001)$. Superior growth potential with a concomitant lower feed intake was confirmed for boars compared to barrows. Energy and lysine levels of the diets exerted only minor effects on the measured variables, such as the intake $(P<0.05)$ and conversion rate $(P<0.01)$ of lysine and energy.

It was concluded that boars grew faster than barrows even though they consumed less feed. Boars and barrows responded to different lysine and metabolised energy levels of the diets in a similar manner suggesting the marked and dominating effect of sex.
\end{abstract}

Keywords: pig, growth performance, voluntary feed intake, lysine, energy

Abbreviations: DWG: daily weight gain; Lys: Lysin; ME: metabolised energy; VFI: voluntary feed intake

Archiv Tierzucht 56 (2013) 39, 399-409

doi: 10.7482/0003-9438-56-039

Corresponding author:

Andreas Berk; email: andreas.berk@fli.bund.de

Institute of Animal Nutrition, Friedrich-Loeffler-Institute (FLI), Federal Research Institute for Animal Health, 38116 Braunschweig, Germany

(c) 2013 by the authors; licensee Leibniz Institute for Farm Animal Biology (FBN), Dummerstorf, Germany. This is an Open Access article distributed under the terms and conditions of the Creative Commons Attribution 3.0 License (http://creativecommons.org/licenses/by/3.0/).
Received: 5 September 2012

Accepted: 15 January 2013 Online: 22 March 2013 


\section{Introduction}

Animal-rights activists demand meat production with more emphasis on animal welfare. The surgical castration of male piglets is one of the points under criticism. The castration of male piglets without anaesthesia is traditionally practiced in many European countries to avoid a boar taint. Nevertheless, in recent years it has become a significant concern in animal welfare. Research has proven that this surgical procedure inflicts pain on piglets (Prunier et al. 2006). For animal welfare reasons, the pig sector planned to voluntarily end the practice of surgical castration of pigs in the EU in 2018 (Anonymous 2010). Currently, boar (entire male pig) fattening seems to be one of the most likely alternatives to the surgical castration of pigs.

Under ad libitum feeding conditions, voluntary feed intake (VFI) determines overall performance and is regulated by a number of animal and dietary factors. The growth rate is influenced if VFI is compromised for any reason (Henry 1985). The aim of conventional pork production is to maximise daily weight gain and feed efficiency resulting in lower production costs. This makes the importance of VFI in animal production evident. Indeed, boars are considered to be superior to barrows (castrated male pigs) with regard to the performance. For example, there are differences in the VFI of boars and barrows. Dunshea et al. (2001) measured between $19 \%$ and $12 \%$ higher feed intakes by barrows than boars, depending on their age. VFI is influenced by several factors, including the physiological status (age, body weight) (Kanis \& Koops 1990, Quiniou et al. 2000). The type of pig (breed, sex) (Fuller et al. 1995) affects the VFI as well as the composition of the feed (Henry 1985) and the outside temperature do(Quiniou et al. 2000).

Although the feed intake of boars is lower, the growth performance of boars is higher (Dunshea et al. 1993, Andersson et al. 1997). Consequently, boars have a superior feed efficiency (Bonneau et al. 1994, Van Lunen \& Cole 1996) with a higher weight gain (Campbell \& Taverner 1988, Van Lunen \& Cole 1996) and, at the same time, lower feed consumption (Dunshea et al. 1993, Dunshea et al. 2001).In addition, the carcasses of boars are leaner than those of barrows (Dunshea et al. 2001, Gispert et al. 2010, Boler et al. 2011). The growth performance of pigs depends on the first limiting amino acid lysine (Lys) and the energy content of the diet. Inappropriate Lys-to-metabolised energy (ME) ratios might result in depressive growth performance of pigs (Campbell \& Taverner 1988).

Therefore, the aim of the present study was to examine selected Lys-to-energy levels as supposed causes for the specific differences in VFI and growth performance of boars and barrows.

\section{Material and methods}

\section{Experimental design and diets}

A total of 95 crossbred pigs (Piétrain $\times$ [Large WhitexLandrace]), 48 boars and 47 barrows obtained from a commercial breeder, were included in this feeding trial. To simplify matters, the difference between these two groups is described as sex. Before the experiment started, the piglets were reared from the average live weight of $8 \mathrm{~kg}$ to $25 \mathrm{~kg}$ in pens with five pigs of the same sex per pen. Afterwards they were transferred to the experimental unit and switched to their respective treatment diets. The experimental period spanned the live weight range from an average of $27 \mathrm{~kg}$ up to the time of slaughter at $120 \mathrm{~kg}$. 
The pigs were randomly allotted to four diets in a $2 \times 2 \times 2$ factorial arranged design with the fixed factors sex, energy level and lysine level and their interactions.

The feeding regimen was a two phase feeding, with an individual change from grower to finisher diet at approximately $75 \mathrm{~kg}$ live weight.

There were four feeding groups for each sex; each feeding group included 24 animals (12 boars and 12 barrows); except the high Lys, high ME feeding group with only 11 barrows. Four dietary mixtures with two different Lys-to-ME ratios were used. The Lys-to-ME ratio was lowered from 0.93 to $0.86(\mathrm{~g} / \mathrm{MJ})$ for the grower diets and from 0.71 to $0.66(\mathrm{~g} / \mathrm{MJ})$ for the finishing diets. The feed composition and analysis of the diets are given in Table 1.

Table 1

Feed composition and analysis

\begin{tabular}{|c|c|c|c|c|c|c|c|c|}
\hline $\begin{array}{l}\text { Lys, ME level } \\
\text { period }\end{array}$ & $\begin{array}{l}\text { High/low } \\
\text { Grower }\end{array}$ & $\begin{array}{l}\text { High/low } \\
\text { Finisher }\end{array}$ & $\begin{array}{l}\text { High/high } \\
\text { Grower }\end{array}$ & $\begin{array}{l}\text { High/high } \\
\text { Finisher }\end{array}$ & $\begin{array}{l}\text { Low/low } \\
\text { Grower }\end{array}$ & $\begin{array}{l}\text { Low/low } \\
\text { Finisher }\end{array}$ & $\begin{array}{l}\text { Low/high } \\
\text { Grower }\end{array}$ & $\begin{array}{l}\text { Low/high } \\
\text { Finisher }\end{array}$ \\
\hline \multicolumn{9}{|l|}{ Components, $\%$} \\
\hline Wheat & 30.00 & 32.00 & 30.00 & 32.00 & 30.00 & 32.00 & 30.00 & 32.00 \\
\hline Barley & 38.19 & 41.70 & 39.87 & 43.75 & 38.45 & 41.90 & 40.17 & 44.00 \\
\hline Soy bean meal & 22.00 & 17.50 & 22.00 & 17.50 & 22.00 & 17.50 & 22.00 & 17.50 \\
\hline Soy bean oil & 2.00 & 2.00 & 3.40 & 3.30 & 2.00 & 2.00 & 3.40 & 3.30 \\
\hline Mineral-vitamin premix ${ }^{*}$ & 3.00 & 2.50 & 3.00 & 2.50 & 3.00 & 2.50 & 3.00 & 2.50 \\
\hline Cellulose & 3.30 & 3.50 & - & - & 3.30 & 3.50 & - & - \\
\hline Lysine- $\mathrm{HCl}$ & 0.66 & 0.40 & 0.75 & 0.48 & 0.55 & 0.32 & 0.64 & 0.39 \\
\hline DL-Methionine & 0.50 & 0.25 & 0.55 & 0.27 & 0.40 & 0.18 & 0.47 & 0.20 \\
\hline L-Threonine & 0.30 & 0.15 & 0.35 & 0.17 & 0.25 & 0.10 & 0.27 & 0.11 \\
\hline L-Tryptophane & 0.05 & - & 0.08 & 0.03 & 0.05 & - & 0.05 & - \\
\hline \multicolumn{9}{|c|}{ Feed calculated lysine and energy content } \\
\hline $\mathrm{ME}, \mathrm{MJ} / \mathrm{kg}^{* *}$ & 12.79 & 12.81 & 13.60 & 13.61 & 12.78 & 12.79 & 13.60 & 13.59 \\
\hline Gross Lys, g/kg & 12.80 & 10.00 & 13.60 & 10.60 & 12.00 & 9.30 & 12.70 & 10.00 \\
\hline Pcd Lys, g/kg*** & 11.85 & 9.04 & 12.57 & 9.69 & 11.04 & 8.45 & 11.76 & 9.03 \\
\hline Pcd Lys:ME & 0.93 & 0.71 & 0.93 & 0.71 & 0.86 & 0.66 & 0.86 & 0.66 \\
\hline \multicolumn{9}{|l|}{ Analysed composition, \% } \\
\hline $\mathrm{ME}, \mathrm{MJ} / \mathrm{kg}^{* *}$ & 13.00 & 12.89 & 13.77 & 13.80 & 13.45 & 12.85 & 13.76 & 13.77 \\
\hline Dry matter, $\%$ & 89.35 & 88.92 & 89.43 & 89.00 & 92.12 & 88.74 & 89.53 & 88.78 \\
\hline Crude protein & 17.71 & 15.91 & 17.85 & 16.61 & 17.95 & 16.20 & 17.99 & 16.21 \\
\hline Lysine, $\mathrm{g} / \mathrm{kg}$ & 13.10 & 10.20 & 13.60 & 11.30 & 12.30 & 9.90 & 13.20 & 10.20 \\
\hline Crude fat & 4.09 & 3.73 & 5.19 & 5.40 & 4.58 & 3.57 & 5.02 & 5.45 \\
\hline Crude fiber & 6.64 & 6.01 & 4.52 & 3.67 & 6.68 & 6.15 & 4.46 & 4.35 \\
\hline Crude ash & 5.37 & 4.74 & 5.47 & 4.79 & 5.80 & 4.79 & 5.48 & 4.73 \\
\hline
\end{tabular}

*Per kg diet (for grower with 3\% premix): vitamin A, $8000 \mathrm{IU}$; vitamin $\mathrm{D}_{3^{\prime}}, 800 \mathrm{IU}$; vitamin $\mathrm{E}, 24 \mathrm{mg}$; vitamin $\mathrm{K}_{3^{\prime}}, 1.05 \mathrm{mg}$; vitamin $B_{1}, 0.75 \mathrm{mg}$; vitamin $B_{2}, 2.0 \mathrm{mg}$; vitamin $B_{12}, 0.015 \mathrm{mg}$; vitamin $B_{6}, 2.0 \mathrm{mg}$; calcium pantothenate, $6.75 \mathrm{mg}$; nicotinic acid, $10 \mathrm{mg}$; choline chloride, $100 \mathrm{mg} ; \mathrm{Ca}, 5 \mathrm{~g} ; \mathrm{Na}, 1.1 \mathrm{~g} ; \mathrm{Mg}, 0.2 \mathrm{~g} ; \mathrm{Fe}, 80 \mathrm{mg}$; Cu, $10 \mathrm{mg}$; Co, $0.55 \mathrm{mg} ; \mathrm{Zn}, 67 \mathrm{mg}$; $\mathrm{Mn}, 55 \mathrm{mg} ; \mathrm{I}, 1.35 \mathrm{mg}$; Se, $0.25 \mathrm{mg}$ ， ${ }^{* *}$ Calculated on base of digestible (table values of the used compounds) crude nutrients (as analysed) according to GfE (2008), ***Pcd Lys: precaecally digestible lysine; calculated on base of (GfE 2005)

\section{Housing and management}

The pigs were housed individually in boxes on concrete floor during the experimental period. The box dimension was $3.1 \mathrm{~m}^{2}$. Water was provided ad libitum via nipple drinkers. All pigs were able to consume the experimental diets as mash feed on ad libitum basis. Boars and barrows were housed alternately in the experimental barn to avoid housing effects. Minimum temperatures in the pig house were kept at above $18^{\circ} \mathrm{C}$. Every pig had 
an own feed bucket which contained $10 \mathrm{~kg}$ of the respective experimental diet and was refilled after the pig emptied it. Feeding and refilling was done manually and recorded daily. All pigs were weighed before the beginning and at the end of the trial. The pigs were weighed weekly over the experimental period. The study was conducted at the experimental station of the Institute of Animal Nutrition, Friedrich-Loeffler-Institute (FLI), Braunschweig, Germany.

\section{Analysis}

Samples of each diet were collected and analysed for dry matter and proximate constituents according to the methods of the VDLUFA (2007). Crude protein in the diets was analysed using the method of Dumas (Method Number 4.1.2). Crude fat, crude fibre and crude ash were analysed according to Methods 5.1.1, 6.1.1 and 8.1, respectively. Furthermore, the diets were analysed for sugar (according to Luff-Schoorl) and starch (polarmetrically).

The amino acid content, with the exception of tryptophan, was analysed by ion exchange chromatography using an Amino Acid Analyser (Biochrom Ltd., Cambridge, UK). Tryptophan was determined by HPLC with fluorescence detection (Anonymous 2000).

\section{Calculation and statistics}

Daily weight gain (DWG) was calculated as the difference between end weight minus start weight divided by days of the feeding period. Daily feed intake was calculated weekly, as the difference between the amount of offered feed and the amount of feed remaining at the end of a test period, divided by the number of days of that test period. Energy and lysine intake were calculated by multiplying the feed intake by the corresponding energy and lysine concentrations. The feed conversion rate was obtained as feed intake divided by gain. Energy and lysine conversion ratio were assessed by dividing the energy and lysine intakes by the corresponding weight gains.

The experimental data were analysed using the ANOVA procedure of Statistica 10 (StatSoft, Inc.,Tulsa, OK, USA). The effects of sex, energy level and lysine level and their interactions were included in the model:

$$
y_{i j k l}=\mu+a_{i}+b_{j}+c_{k}+a b_{(i j)}+a c_{(i k)}+b c_{(j k)}+a b c_{(j i k)}+e_{i j k l}
$$

where $y_{i j k l}$ is the 1st observation related to the sex $i$, lysine level $j$ and energy level $k$; $\mu$ is the overall mean; $a_{i}$ is the effect of sex; $b_{j}$ is the effect of lysine level; $c_{k}$ is the effect of energy level; $a b_{(i j)}$ is the interaction between sex and lysine level; $a c_{(i k)}$ is the interaction between sex and energy level; $b c_{(j k)}$ is the interactions between lysine level and energy level; $a b c_{(j k)}$ is the interaction between sex, lysine level and energy level and $e_{i j k l}$ is the error term.

Arithmetic means, their pooled standard errors, levels of significance for main effects and the interaction were determined. $P$-values $<0.05$ were considered to be significant. Besides the ANOVA-based evaluation of the general performance data, the live weight progression of individual pigs and the differences between the sexes were evaluated by fitting to a growth function according to Gompertz (1825):

$$
y=a e^{-b e^{-c t}}
$$


The time point of the maximum daily weight gain, which coincides with the inflection point of the cumulative sigmoid growth curve, can be deduced from the second derivative of the growth function:

$$
t_{\max }=\frac{\ln b}{c}
$$

where $y$ is the live weight in $\mathrm{kg}, a$ is a parameter of the function (asymptotic live weight [kg] at infinity, $b$ and $c$ are paprameters of the function, $t$ is the time (d) and $t_{\max }$ is the time at maximum DWG $(\mathrm{d})$.

Individual data were fitted to the growth curve using the iterative Quasi-Newtonprocedure implemented in the Statistica software package (StatSoft, Inc. Tulsa, OK, USA).

\section{Results}

Initial and final weights were defined by the design of the trial; accordingly they were similar, $27.6 \pm 0.98 \mathrm{~kg}$ ( \pm standard deviation) for initial weight and $124.1 \pm 4.29 \mathrm{~kg}$ for final weight.

Boars and barrows had different $(P<0.001$, Table 2$)$ growth performance and feed intake. The average DWG of boars was $1188 \mathrm{~g} / \mathrm{d}$ compared to $1107 \mathrm{~g} / \mathrm{d}$ for barrows, respectively. On average, boars consumed $10 \%$ less feed than barrows over the whole experimental period. Accordingly, boars had an improved feed conversion ratio, which was approximately $16 \%$ lower compared to barrows.

No effects were observed for the level of energy or lysine on DWG, VFI or feed conversion ratio (Table 2). The values for precaecally digestible lysine were calculated in this study (Table 1), but not determined analytically. The analysis that follows accordingly relates to gross lysine values. The values for gross lysine were analysed in the present study, thus these values were used in the results and discussion section. However, the lysine level affected the lysine intake $(P<0.05)$ and as consequence the corresponding lysine conversion ratios $(P<0.01)$. The lysine intake and lysine conversion ratio for boars and barrows increased, depending on the lysine level of the diet. Animals receiving a high lysine diet had an increased lysine intake and lysine conversion ratio.

The energy level also influenced the energy intake $(P<0.05)$ and the energy conversion ratio $(P<0.01)$ and also the lysine intake $(P<0.05)$ and the lysine conversion ratio $(P<0.01)$. The ME level also had an increasing effect on ME intake, ME conversion ratio as well as on the lysine intake and lysine conversion ratio of boars and barrows. Just like the lysine level, pigs fed diets with a high ME level had increased ME variables.

Pigs of both sexes responded to dietary treatments in a similar manner as indicated by the absence of any significant interaction between sex and lysine or ME levels. Nevertheless there were several significant interactions observed between Lys $\times$ ME level and growth parameters. These interactions were presented as pooled values for both sexes in the whole experimental period. Feed intake, energy intake, lysine intake and energy conversation ratio interacted $(P<0.05)$ with the Lys $\times$ ME level. The highest VFI was observed for the pigs who received the low Lys and low ME diet ( $2.90 \mathrm{~kg} / \mathrm{d}$; arithmetic mean of both sexes). The animals in the other three feeding groups had a similar VFI between $2.76 \mathrm{~kg} / \mathrm{d}$ and $2.80 \mathrm{~kg} / \mathrm{d}$. Additionally, the pigs fed with the two diets with decreased Lys-to-ME ratio $(0.86$ or respectively $0.66 \mathrm{~g} / \mathrm{MJ})$ 
presented higher deviation in VFI than that pigs consumed the two diets with increased Lys-to-ME ratio ( 0.93 or respectively $0.71 \mathrm{~g} / \mathrm{MJ}$ ). These relationships were responsible for the significant interaction between Lys $\times$ ME level for VFI. Another interaction was determined between Lys $\times$ ME level and ME intake. The pigs which were fed the diet with high lysine and high ME level had the highest ME intake (38.47 MJ ME/d), those which were fed the low lysine and high ME feed showed the lowest ME intake (35.73 MJ ME/d). Furthermore the Lys $\times M E$ level interacted $(P<0.05)$ with the $M E$ conversion ratio. Animals receiving the low lysine and high ME diet showed the most advantageous energy conversion ratio (31.36 MJ/kg). The pigs supplied with the other three diets had similar energy conversion ratios of between $33.15 \mathrm{MJ} / \mathrm{kg}$ and $33.40 \mathrm{MJ} / \mathrm{kg}$. The interaction of Lys $\times M E$ level with lysine and ME intake also depends on the amount of VFI. In consequence, these relationships influenced the significant interaction between Lys $\times$ ME level and the ME conversion ratio.

Table 2

$\mathrm{N}$ retention and nutrient digestibility in N Balance Studies 1 and 2 (least square means and pooled standard error of means)

\begin{tabular}{|c|c|c|c|c|c|c|c|c|c|}
\hline \multirow[t]{3}{*}{$\mathrm{N}$ balance study 1} & \multicolumn{3}{|c|}{ Period } & \multicolumn{3}{|c|}{ Diet } & \multirow[t]{3}{*}{ PSEM } & \multirow{2}{*}{\multicolumn{2}{|c|}{$\begin{array}{c}\text { ANOVA } \\
(P \text {-value })^{*}\end{array}$}} \\
\hline & \multirow[t]{2}{*}{1} & \multirow[t]{2}{*}{2} & \multirow[t]{2}{*}{3} & \multirow[t]{2}{*}{1} & \multirow[t]{2}{*}{2} & \multirow[t]{2}{*}{3} & & & \\
\hline & & & & & & & & Period & Diet \\
\hline N-Ret, g/kg BW 0.67 & 1.87 & 1.89 & 1.81 & 1.78 & 1.93 & 1.85 & 0.02 & 0.305 & 0.067 \\
\hline N-Ret, g/d & $24.32^{c}$ & $27.96^{b}$ & $30.78^{a}$ & 26.71 & 28.70 & 27.65 & 0.38 & $<0.001$ & 0.163 \\
\hline N-Utilisation, $\%$ & 60.75 & 61.08 & 58.76 & 60.35 & 61.32 & 58.91 & 1.46 & 0.326 & 0.347 \\
\hline$d X P, \%$ & $83.74^{b}$ & $86.11^{\mathrm{a}}$ & $88.04^{\mathrm{a}}$ & $84.14^{b}$ & $87.14^{a}$ & $86.61^{\mathrm{ab}}$ & 0.31 & $<0.01$ & 0.025 \\
\hline $\mathrm{dOM}, \%$ & 86.90 & 87.54 & 88.05 & $85.65^{b}$ & $88.36^{a}$ & $88.48^{\mathrm{a}}$ & 0.30 & 0.238 & $<0.01$ \\
\hline $\mathrm{dXL}, \%$ & 71.06 & 71.36 & 69.82 & 70.98 & 71.20 & 70.06 & 1.36 & 0.752 & 0.854 \\
\hline$d X F, \%$ & 33.77 & 36.09 & 38.27 & 32.61 & 34.29 & 41.23 & 2.42 & 0.388 & 0.062 \\
\hline$d X X, \%$ & 91.99 & 92.00 & 92.11 & $90.76^{b}$ & $92.55^{\mathrm{a}}$ & $92.78^{\mathrm{a}}$ & 0.19 & 0.936 & 0.003 \\
\hline \multicolumn{10}{|l|}{$\mathrm{N}$ balance study 2} \\
\hline N-Ret,g/kg BW 0.67 & 1.61 & 1.62 & 1.67 & $1.52^{\mathrm{b}}$ & $1.66^{\mathrm{a}}$ & $1.72^{\mathrm{a}}$ & 0.14 & 0.360 & $<0.01$ \\
\hline N-Ret, g/d & $21.05^{\mathrm{b}}$ & $23.93^{b}$ & $28.24^{\mathrm{a}}$ & $22.38^{b}$ & $24.72^{\mathrm{ab}}$ & $26.11^{\mathrm{a}}$ & 1.27 & $<0.01$ & 0.028 \\
\hline N-utilisation, $\%$ & 59.62 & 58.25 & 60.09 & $54.21^{\mathrm{b}}$ & $61.79^{a}$ & $61.96^{\mathrm{a}}$ & 4.56 & 0.638 & 0.016 \\
\hline $\mathrm{dXP}, \%$ & $82.66^{b}$ & $84.78^{\mathrm{ab}}$ & $87.34^{a}$ & $82.39^{b}$ & $86.38^{a}$ & $86.01^{\mathrm{a}}$ & 1.34 & 0.016 & 0.015 \\
\hline $\mathrm{dOM}, \%$ & 84.44 & 85.48 & 86.92 & 83.69 & 86.79 & 86.36 & 0.87 & 0.136 & 0.055 \\
\hline$d X L, \%$ & $66.42^{\mathrm{b}}$ & $69.55^{\mathrm{ab}}$ & $71.84^{\mathrm{a}}$ & $71.03^{\mathrm{a}}$ & $69.51^{\mathrm{ab}}$ & $67.28^{b}$ & 1.81 & $<0.01$ & 0.037 \\
\hline$d X F, \%$ & 25.58 & 30.99 & 36.52 & 33.67 & 30.74 & 28.69 & 3.93 & 0.057 & 0.340 \\
\hline$d X X, \%$ & 90.01 & 90.42 & 91.22 & 89.43 & 91.24 & 90.98 & 0.72 & 0.216 & 0.060 \\
\hline
\end{tabular}

*period $\times$ diet were non-significant $(P<0.05)$, Values with different superscripts differ significantly $(P<0.05), \quad N-R e t$ : $\mathrm{N}$ retention, dXP: digestibility of crude protein, dOM: digestibility of organic matter, dXL: digestibility of crude lipid, dXF: digestibility of crude fiber, $d X X$ : digestibility of nitrogen free extractives

As daily weight gain was exclusively influenced by sex, the individual live weight data were subjected to growth curve evaluation independent of dietary lysine and ME level. Thus, pooled boar and pooled barrow data were fitted to the Gompertz function (Figure 1 and 2). Due to live weight-matched individual termination in the experiment, the growth curve evaluation was performed only until day 78 of the experiment, while all pigs were still in the experiment.

Figure 1 showed differences between the sexes in the growth curves. The barrows needed a longer period of time to reach the same weights as boars, although there was no difference in mean live weight at the start of the study. At the beginning of the trial, boars and barrows 
showed similar weight development. During the middle of the trial boars started to grow faster than barrows. After 78 days in trial, the boars weighed on average $117.8 \mathrm{~kg}$, whereas barrows weighed only $112.5 \mathrm{~kg}$ on average.

The boars showed a clearly faster gaining rate than barrows, with, for example, significantly higher weight gain at the end of trial. The DWG of boars was approximately $7 \%$ higher than the DWG of barrows (Figure 2). There was an obvious short term reduction in DWG for boars on the $43 \mathrm{rd}$ day of trial when the average live weight was $75 \mathrm{~kg}$. On day 36 the boars gained $1224 \mathrm{~g} / \mathrm{d}$, which decreased to $1157 \mathrm{~g} / \mathrm{d}$ on day 43, and afterwards increased to $1351 \mathrm{~g} / \mathrm{d}$ on day 50 . Additionally the feed intake of boars was temporarily reduced during this period. Barrows had a less clearly reduced DWG between the 36th and 43rd experimental day. The DWG of barrows decreased from the 29 th day $(1166 \mathrm{~g} / \mathrm{d})$ to day $36(1085 \mathrm{~g})$ and then slowly increased from day 43 (1 $104 \mathrm{~g})$ until day 50 (1 $282 \mathrm{~g})$.
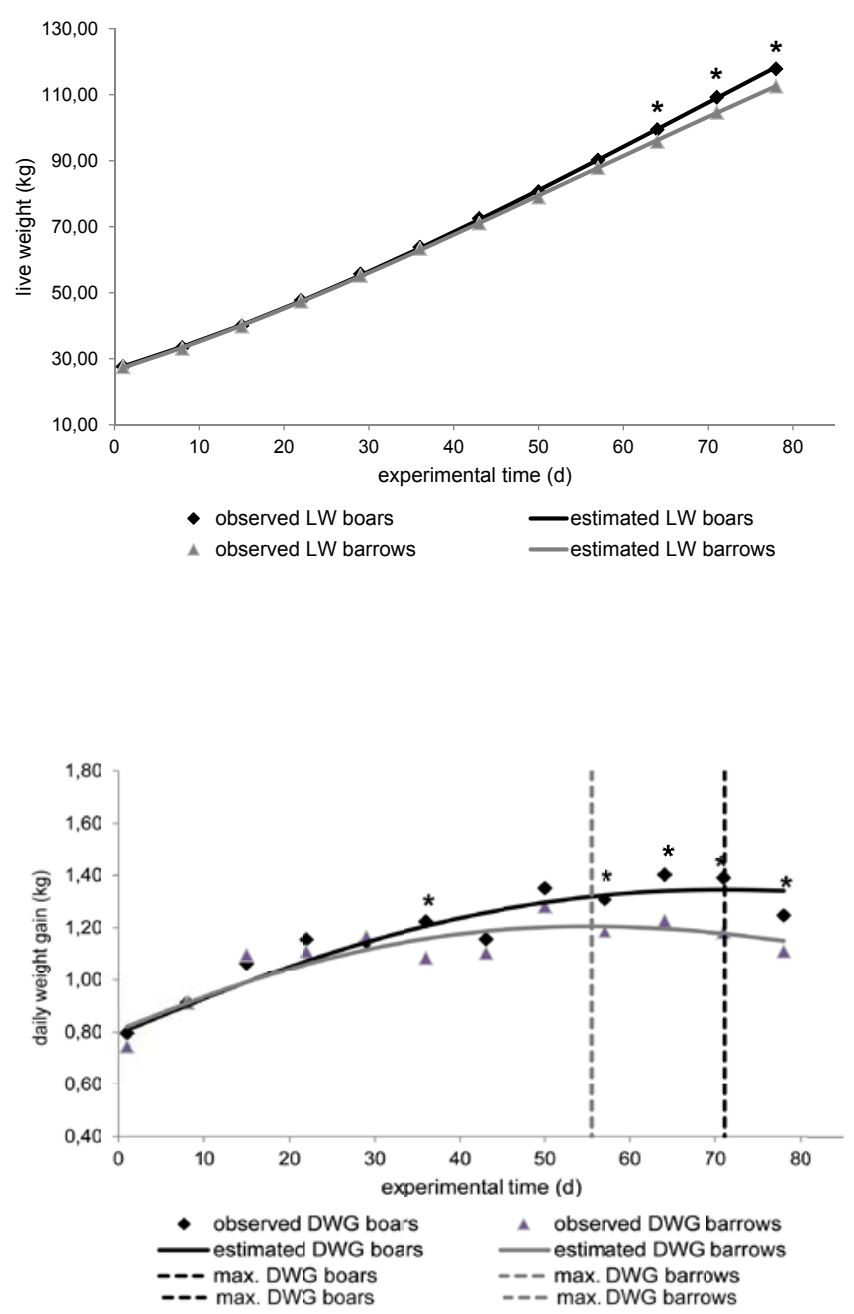

*Values differ significantly $(P<0.05)$

Figure 1

Live weight (LW) development in dependence on time and sex
*Values differ significantly $(P<0.05)$

Figure 2

Daily weigh gain development in dependence on time and sex 
While matching the observed and estimated daily weight gain and calculating the point of maximum gain, it becomes obvious that boars have a 16-day longer increasing gain curve to meet this point than barrows (experimental day 55 for barrow compared to day 71 for boars, Table 3).

After splitting the whole experimental period into several live weight stages, statistical analysis only showed sex effects $(P<0.05)$ on DWG from $90 \mathrm{~kg}$ live weight until the end of the trial. No significant sex effects were observed for DWG before $90 \mathrm{~kg}$ live weight (data not shown).

\section{Discussion}

The present experiment is aimed at examining two lysine-to-ME ratios as supposed causes for the specific differences in feed intake and growth performance between boars and barrows. In accordance with current literature, the superior performance of boars was also confirmed in the present experiment.

During the whole experimental period the growth performance of boars was higher than that of barrows. In the present study boars had an improved feed conversion ratio, approximately $16 \%$ lower than barrows. Several authors mentioned the more efficient feed conversion ratio of boars compared to barrows (Campbell et al. 1989, Karg 1994, Van Lunen \& Cole 1996, Dunshea et al. 2001). In agreement with the results of Zeng et al. (2002) and Quiniou et al. (1999), barrows on average consumed more feed than boars on average in the whole experimental period. Forbes (1995) referred to the relationship between VFI and composition of the feed, hormone concentration and other influencing factors. One explanation for the sex difference in performance was the anabolic effects of gonad steroid hormones. Testosterone and oestradiol were found to reduce VFI in pigs, the combined action of steroids determined the reduced feed intake in boars compared to barrows (Claus \& Weiler 1994).

Pigs that had been fed with low density lysine and energy feed (decreased Lys-to-ME ratio) consumed more feed than pigs that had been fed other lysine and ME levels as suggested by the significant interactions between lysine level and ME concentration. The significant difference between VFI of pigs fed the low density lysine and energy diet and pigs fed the other diets suggests that pigs are able to balance a deficit of lysine and/or ME in the diet by increasing their VFI. This observed animal adaption was confirmed by the findings described by Henry (1985). In addition and relating to these results, the pigs that consumed the diet with the high lysine and high ME level should have the lowest VFI.

Contrary to these expectations, in the present study the animals received the high lysine and high ME level had the second highest VFI and not the lowest VFI. Hence, no evidence could be found, that lysine or energy were major factors affecting VFI.

Comparing the live weight development of boars and barrows, it becomes obvious, that boars reached the point of maximum daily gain 16 days later than barrows. As a consequence, the time of increasing DWG lasted longer for boars than for barrows. After reaching the point of maximum daily gain, boars and barrows had relatively higher maintenance requirements than performance requirements proportional to the total demand of ME. This fact suggests a more efficient growth of boars compared to barrows, because of their long term increasing gain curve. 
A similar study, Andersson et al. (1997) also described a decreased weight gain of barrows compared to boars. Contrary to these results, Zamaratskaia et al. (2008) obtained lower daily weight gain for boars. Other authors observed similarly high growth rates for boars with $1015 \mathrm{~g} / \mathrm{d}$ (Schulze et al. 2002), $1025 \mathrm{~g} / \mathrm{d}$ (Von Felde et al. 1996) and $1110 \mathrm{~g} / \mathrm{d}$ (Fuller et al. 1995) emphasizing the findings in the present study.

Zhang et al. (2011) demonstrated that average daily weight gain increased for growing finishing pigs as the lysine-to-energy ratio increased. Other authors also observed improved performance if the lysine-to-energy ratio was increased (Friesen et al. 1994, De la Llata et al. 2007). In contrast, in the current study an increased level of lysine and ME had no effect on DWG or feed conversion ratio (related to the average feeding group data). The lack of significant effects of the Lys-to-ME ratio concerning growth parameters might be an indication that possibly the chosen Lys-to-ME ratios do not differ clearly enough.

Apart from this, the energy level effected the amount of energy intake and lysine intake $(P<0.05)$ and as a consequence of this also the energy and lysine conversion ratio $(P<0.01)$. The lysine level also influenced the amount of lysine intake and the lysine conversation ratio $(P<0.001)$. These results are caused by the amount of feed intake and the concentration of lysine and/ or ME in the diet.

Phase feeding is a common practice in pig production in order to best meet the nutrient requirement of the growing animal. However, pigs react and are sensitive to unfamiliar diets and often decrease their VFI. As a result, the DWG may be depressed during the adaption period (Dong \& Pluske 2007, Clouard et al. 2012). According to these findings, the decrease in DWG during the middle of the current experiment might be explained by the change from starter to finisher feed at this time. Boars showed this reduction more clearly than barrows. Indeed, boars seemed only to consume the amount of feed they required for optimum growth. Therefore, the reduced feed intake had a direct effect on the DWG on the 43rd experimental day. However, barrows had a higher feed intake and animal-individual deviations obliterate the small decrease in VFI.

The data from the present study clearly pointed out the superior growth performance of boars compared to barrows. However, it must be noted that this data was received under experimental conditions and does not represent practical growth performance. Nevertheless, the differences between boars and barrows were also reported in group-housed pigs although on a lower performance level (Andersson et al. 1997). In general, the housing conditions can influence the feed intake. Bornett et al. (2000) reported that individually penned pigs showed a different feed intake behaviour than group-housed pigs, caused for example by aggression or social stress. The present study investigated the feed consumption of individually penned pigs only. Therefore, more research is required to compare the feed intake of single and group-housed pigs.

In conclusion, the superior growth performance potential of boars compared to barrows was confirmed in the present experiment. Barrows and boars responded to different lysine and ME levels of the diets in a similar manner, suggesting the marked and dominating effect of sex. 


\section{Acknowledgements}

The authors would like to thank the co-workers of the Institute of Animal Nutrition of the Friedrich-Loeffler-Institute (FLI) in Braunschweig Germany, for assistance in performing the experiment and the analyses.

\section{References}

Andersson K, Schaub A, Andersson K, Lundström K, Thomke S, Hansson I (1997) The effects of feeding system, lysine level and gilt contact on performance, skatole levels and economy of entire male pigs. Livest Prod Sci 51, 131-140

Anonymous (2000) Commission Directive 2000/45/EC of 6 July 2000, establishing Community methods for the determination of vitamin A, vitamin $E$ and tryptophan, annex part C. Determination of Tryptophan. Official Journal of the European Communities, L174 45-50

Anonymous (2010) European Declaration on alternatives to surgical castration of pigs. http://ec.europa.eu/ food/animal/welfare/farm/docs/castration_pigs_declaration_en.pdf [last accessed 22.02.2013]

Boler DD, Kutzler LW, Meeuwse DM, King VL, Campion DR, McKeith FK, Killefer J (2011) Effects of increasing lysine on carcass composition and cutting yields of immunologically castrated male pigs. J Anim Sci 89, 2189-2199

Bonneau M, Dufour R, Chouvet C, Roulet C, Meadus W, Squires EJ (1994) The effects of immunization against luteinizing hormone-releasing hormone on performance, sexual development, and levels of boar taintrelated compounds in intact male pigs. J Anim Sci 72, 14-20

Bornett HLI, Morgan CA, Lawrence AB, Mann J (2000) The effect of group housing on feeding patterns and social behaviour of previously individually housed growing pigs. Appl Anim Behav Sci 70, 127-141

Campbell RG, Steele NC, Caperna TJ, McMurtry JP, Solomon MB, Mitchell AD (1989) Interrelationships Between Sex and Exogenous Growth Hormone Administration on Performance, Body Composition and Protein and Fat Accretion of Growing Pigs. J Anim Sci 67, 177-186

Campbell RG, Taverner MR (1988) Genotype and Sex Effects on the Relationship Between Energy Intake and Protein Deposition in Growing Pigs. J Anim Sci 66, 676-686

Claus R, Weiler U (1994) Endocrine regulation of growth and metabolism in the pig: a review. Livest Prod Sci $37,245-260$

Clouard C, Meunier-Salaün MC, Val-Laillet D (2012) The effects of sensory functional ingredients on food preferences, intake and weight gain in juvenile pigs. Appl Anim Behav Sci 138, 36-46

De la Llata M, Dritz SS, Tokach MD, Goodband RD, Pas, Nelssen JL (2007) Effects of Increasing Lysine to Calorie Ratio and Added Fat for Growing-Finishing Pigs Reared in a Commercial Environment: I. Growth Performance and Carcass Characteristics. Prof Anim Sci 23, 417-428

Dong GZ, Pluske JR (2007) The Low Feed Intake in Newly-weaned Pigs: Problems and Possible Solutions. Asian Aust J Anim Sci 20, 440-452

Dunshea FR, Colantoni C, Howard K, McCauley I, Jackson P, Long KA, Lopaticki S, Nugent EA, Simons JA, Walker J, Hennessy DP (2001) Vaccination of boars with a GnRH vaccine (Improvac) eliminates boar taint and increases growth performance. J Anim Sci 79, 2524-2535

Dunshea FR, King RH, Campbell RG, Sainz RD, Kim YS (1993) Interrelationships between sex and ractopamine on protein and lipid deposition in rapidly growing pigs. J Anim Sci 71, 2919-2930

Forbes JM (1995) Voluntary feed intake and diet selection in farm animals. CAB International, Wallingford, UK, $152-185$

Friesen KG, Nelssen JL, Goodband RD, Tokach MD, Unruh JA, Kropf DH, Kerr BJ (1994) Influence of dietary lysine on growth and carcass composition of high-lean-growth gilts fed from 34 to 72 kilograms. J Anim Sci 72, 1761-1770 
Fuller MF, Franklin MF, McWilliam R, Pennie K (1995) The responses of growing pigs, of different sex and genotype, to dietary energy and protein. J Anim Sci 60, 291-298

GfE (2005) Standardised precaecal digestibility of amino acids in feedstuffs for pigs - methods and cocepts. Pro. Soc. Nutr. Physiol. 14, 185-205

GfE (2008) Recommendations for the supply of energy and nutrients to pigs. DLG Verlag, Frankfurt/Main, Germany

Gispert M, Àngels Oliver M, Velarde A, Suarez P, Pérez J, Font i Furnols M (2010) Carcass and meat quality characteristics of immunocastrated male, surgically castrated male, entire male and female pigs. Meat Sci $85,664-670$

Gompertz B (1825) On the nature of the function expressive of the law of human mortality, and on a new mode of determining the value of Life Contingencies. Philos Trans R Soc Lond B Biol Sci 115,513-583

Henry Y (1985) Dietary factors involved in feed intake regulation in growing pigs: A review. Livest Prod Sci 12, 339-354

Kanis E, Koops WJ (1990) Daily gain, food intake and food efficiency in pigs during the growing period. Anim Prod 50, 353-364

Karg H (1994) [Hormonal regulation of the growth]. In: Döcke F (ed.) [Veterinary Endocrinology]. 3rd. rev. ed., Gustav Fischer Verlag, Jena u. a., Germany,176-203 [in German]

Prunier A, Bonneau M, von Borell EH, Cinotti S, Gunn M, Fredriksen B, Giersing M, Morton DB, Tuyttens FAM, Velarde $A$ (2006) A review of the welfare consequences of surgical castration in piglets and the evaluation of non-surgical methods. Anim Welf 15, 277-289

Quiniou N, Dubois S, Le Cozler Y, Bernier JF, Noblet J (1999) Effect of growth potential (body weight and breed/ castration combination) on the feeding behaviour of individually kept growing pigs. Livest Prod Sci 61, $13-22$

Quiniou N, Dubois S, Noblet J (2000) Voluntary feed intake and feeding behaviour of group-housed growing pigs are affected by ambient temperature and body weight. Livest Prod Sci 63, 245-253

Schulze V, Roehe R, Lorenzo Bermejo J, Looft H, Kalm E (2002) Genetic associations between observed feed intake measurements during growth, feed intake curve parameters and growing-finishing performances of central tested boars. Livest Prod Sci 73, 199-211

Van Lunen TA, Cole DJA (1996) The effect of lysine/digestible energy ratio on growth performance and nitrogen deposition of hybrid boars, gilts and castrated male pigs. Anim Sci 63, 465-475

VDLUFA (2007) (Verband Deutscher Landwirtschaftlicher Untersuchungs- und Forschungsanstalten) Handbuch der Landwirtschaftlichen Versuchs- und Untersuchungsmethodik (VDLUFA-Methodenbuch), Band III. Die chemische Untersuchung von Futtermitteln. VDLUFA-Verlag, Darmstadt, Germany [in German]

Von Felde A, Roehe R, Looft H, Kalm E (1996) Genetic association between feed intake and feed intake behaviour at different stages of growth of group-housed boars. Livest Prod Sci 47, 11-22

Zamaratskaia G, Andersson HK, Chen G, Andersson K, Madej A, Lundström K (2008) Effect of a Gonadotropinreleasing Hormone Vaccine (ImprovacTM) on Steroid Hormones, Boar Taint Compounds and Performance in Entire Male Pigs. Reprod Domest Anim 43, 351-359

Zeng XY, Turkstra JA, Jongbloed AW, van Diepen JThM, Meloen RH, Oonk HB, Guo DZ, van de Wiel DFM (2002) Performance and hormone levels of immunocastrated, surgically castrated and intact male pigs fed ad libitum high- and lowenergy diets. Livest Prod Sci 77, 1-11

Zhang GJ, Yi XW, Chu LC, Lu N, Htoo J, Qiao SY (2011) Effects of Dietary Net Energy Density and Standardized Ileal Digestible Lysine: Net Energy Ratio on the Performance and Carcass Characteristic of GrowingFinishing Pigs Fed Low Crude Protein Supplemented with Crystalline Amino Acids Diets. Agric Sci China $10,602-610$ 